\title{
Does Revenue-Expense Matching Relate To Going-Concern Audit Opinion Conditional On Firm's Financial Distress?
}

Hak Woon Kim, Ph.D., Sungkyunkwan University, South Korea

Sooro Lee, Ph.D., HyupSung University, South Korea

\begin{abstract}
This paper investigates how firms manage the revenue-expense relationship in the presence of a going-concern audit opinion (GCO). Using Korean data, we find that firms with GCOs both delay and accelerate recognition of current expenses for current revenues. We also find that firms in severe financial distress that receive GCOs exhibit conservative accounting, whereas GCO firms in relatively less financial trouble adopt aggressive accounting. Overall, our results imply that firms' matching extent and behavior provide useful information regarding financial reporting and can explain the earnings management behavior of firms with GCOs.
\end{abstract}

Keywords: Matching; Going-Concern Opinion; Discretionary Accruals; Earnings Management

\section{INTRODUCTION}

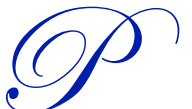

rior studies have examined whether there are associations between low financial reporting quality and a going-concern audit opinion (GCO) ${ }^{1}$. Several studies (Bartov, Gul, and Tsui 2000; Bradshaw, Richardson, and Sloan 2001; Amedo, Lizarraga, and Sanchez 2008) find that a significant relationship between GCOs and accounting accruals implies aggressive accounting, whereas Butler, Leone, and Willenborg (2004) suggest that this association is driven by firms that have large negative accruals and is due mainly to financial distress rather than earnings management. Butler, Leone, and Willenborg (2004) argue that firms with GCOs during periods of severe financial distress ${ }^{2}$ display extreme negative discretionary accruals due to transactions conducted to meet liquidity needs through delays in accounts payable and factor accounting receivables. Our research question in this paper is thus: how do firms manage the revenue-expense relationship in the presence of GCOs? We investigate the association between revenue-expense matching and earnings management by firms that receive GCOs, depending on their financial characteristic variables. More specifically, this study examines whether firms that receive GCOs accelerate recognition of current expenses in the prior period or delay recognition to the following period to manage earnings.

Accelerating or delaying recognition of current expenses on current revenues may appear through the manager's opportunistic accounting choices, under which the manager calculates earnings by artificially adjusting them between accounting periods. Based on prior studies (Dichev and Tang 2008; Paek 2011b), types of matching can be classified into the following three categories: neutral accounting, where current revenue recognizes current expenses in the current period; conservative accounting, whereby current revenues are recognized in the current period, but current expenses are recognized in the prior period by accelerating recognition of current expenses on current revenues; and aggressive accounting, whereby current revenues are recognized in the current period, but current expenses are recognized in the following period by delaying recognition of current expenses. Equivalent to neutral accounting, the more properly current revenues and current expenses are matched, the higher the quality of earnings

\footnotetext{
${ }^{1}$ In this paper, a going-concern audit opinion (GCO) is defined as an auditor's issuance of a going-concern audit opinion for the current fiscal year's financial statements of an audit client that received a clean opinion for the previous fiscal year. Audit firms issue a going-concern opinion to reflect substantial doubt regarding a client's ability to continue as a going concern for one year beyond the financial statement date.

${ }^{2}$ Firms in severe financial distress are defined as those with negative equity, losses, and higher leverage, as in the third tertile of portfolios partitioned by the total liability to equity ratio. This represents the top 30 percent of portfolios.
} 
(Paek 2011b). In addition, when a portion of current expenses is identified early in the prior period under conservative accounting, earnings persistence increases (Paek 2012). Paek (2012) found that net income, cash flow from operations, and market value are higher for a large group with accelerated recognition of current expenses. Moreover, a group with a higher delayed recognition of expenses shows significant differences in the earnings range of loss avoidance $(0.00-0.01)$, which indicates that loss avoidance incentives increase strongly in a large group with a higher delayed recognition of expenses. Application of aggressive accounting is suggested when managers are provided with opportunistic financial reporting incentives through delayed recognition of current expenses (Basu 1997; Bhattacharaya, Daouk, and Welker 2003).

In the United States, the overall subsequent bankruptcy rate within 12 months after receiving a GCO is 12.3 percent (Geiger and Rama 2006). If a firm experiences the critical uncertainty of a going-concern, the firm may have an incentive to consider different types of earnings management, depending on the firm's financial condition. This situation may occur if firms are in severely distressed positions and demonstrate negative equity, losses, and higher leverage, or if firms are insolvent, on the edge of bankruptcy, or without sufficient flexibility in earnings management (Kim, Sin, and Lee 2014). These firms have extremely negative (-) discretionary accruals, which can be interpreted as a firm engaging in downward earnings management (Mutchler, Hoopwood, and McKeown 1997). Moreover, financially troubled firms often deliberately reduce reported earnings because managers attempt to improve short-term cash flow by disposing of inventory or accounts receivable (DeAngelo, DeAngelo, and Skinner 1994). Regarding downward earnings incentives, Holthausen, Larcker, and Sloan (1995) indicate that managers manipulate earnings downwards when earnings reach either the lower bound or the upper bound and when managers' bonuses are at a maximum. This downward earnings management is derived from conservative accounting. When recognizing the phenomenon of extremely negative (-) discretionary accruals as a result of serious financial stress, an auditor tends to adopt a conservative attitude/manner based on high litigation risks related to the business failure of these firms ( $\mathrm{Lu}$ and Sapra 2009). The auditor's conservative approach leads to a reversal of excessive accruals that occurred in the prior period (Kim, Son, and Lee 2013), and auditors may force managers to make noncash write-offs (DeAngelo, DeAngelo, and Skinner 1994). Consequently, financial reporting by management may appear to exhibit conservative accounting, with current expenses recognized earlier.

However, managers of firms with GCOs and in relatively less severe financial distress ${ }^{3}$, such as lower firm performance and leverage, may engage in upward earnings management to disguise their weak performance in prior periods, to bolster investor and stakeholder confidence, or to avoid receiving consecutive GCOs from an auditor (Kim 2013). These firms have positive $(+)$ discretionary accruals. If positive (+) discretionary accruals occur because of a manager's opportunistic behavior, the firm's financial reporting may appear to exhibit aggressive accounting, based on the delayed recognition of current expenses for current revenues. In addition, if a firm's financial stress is not severe, managers may have strong incentives to inflate earnings to bind debt covenants and to rule out interruption of a board meeting (DeAngelo, DeAngelo, and Skinner 1994). This study examines the mutual incompatibility of discretionary accruals by using types of matching revenues and expenses, such as the accelerated or delayed recognition of expenses, depending on the financial characteristic variables of firms that receive GCOs.

Consequently, we first find that the extent of neutral accounting in firms that receive a GCO is extremely low, whereas the level of both accelerated and delayed recognition of current expenses is high, indicating that the manager's intention is primarily to intervene in accounting choices. Second, we find that GCO firms in less financial distress are more likely to inflate earnings through delayed recognition of current expenses related to current revenues. This finding explains why positive $(+)$ discretionary accruals occur in GCO firms facing less financial distress. We conclude that the significant relationship between expense recognition and GCOs is conditional on a firm's financial distress. Third, for GCO firms with higher leverage, losses, or negative equity, conservative accounting occurs through accelerated recognition of current expenses. These firms are more likely to trigger a default of debt repayments, debt restructuring, delisting, the designation of investment consideration, and a market warning by way of a GCO in the audit report. Finally, we find that GCO firms with conservative accounting practices show extremely negative (-) discretionary accruals.

\footnotetext{
${ }^{3}$ Firms in less financial distress are defined as those with lower firm performance and lower leverage, as in the third tertile of portfolios partitioned by the total liability to equity ratio and by earnings before taxes and interest, deflated by lagged total assets. This represents the bottom 30 percent of portfolios.
} 
This study provides two main contributions to the accounting literature. First, GCO firms in less financial distress use aggressive accounting to manage their earnings upward (i.e., income-increasing). This result indicates that firms with GCOs employ different financial reporting depending on the firm's characteristic variables. Second, the financial reporting of GCO firms can be explained more specifically when using the matching extent as a proxy for existing earnings management. This result implies that revenue-expense matching plays a complementary role regarding discretionary accruals as a proxy for earnings management for firms with GCOs.

This study is organized as follows. The research background and hypotheses are developed in reference to prior studies in section II, and the model design for testing the hypotheses and the sample selection procedure are established in section III. Section IV provides the results of the empirical research, and conclusions are stated in section V.

\section{RESEARCH BACKGROUND AND HYPOTHESIS DEVELOPMENT}

\subsection{Research Background}

The matching principle, the basis of accrual accounting, has been a major subject of research related to earnings management, the most widely studied subject area in accounting (Donelson, Jennings, and McInnis 2011). Matching can be categorized into neutral, aggressive, and conservative accounting according to recognition of expenses related to current revenues (Paek 2011a). Neutral accounting refers to the manner in which current revenues and current expenses are most appropriately matched, whereas aggressive or conservative accounting represents delayed or accelerated recognition of current expenses, respectively. For the past 40 years, an increase in earnings volatility and a decrease in earnings persistence have been observed owing to the deteriorating neutrality of accounting (Dichev and Tang 2008); conversely, trends in conservative and aggressive accounting have strengthened (Paek 2011a). Increase neutrality in accounting results in higher quality of earnings in terms of higher earnings persistence, earnings predictability, income smoothing, and earnings response coefficients (Paek 2011b). Additionally, if the portion of current matching is recognized in an accelerated manner in the prior period, earnings persistence will be significantly higher than when the portion of current matching is recognized in a delayed manner (Paek 2012). If there are no managerial opportunistic incentives, current expenses will be recognized in an accelerated manner, or current revenues will be recognized in a delayed manner. Furthermore, if aggressive financial reporting characteristics exist, current expenses will be recognized in a delayed manner, or there will be an accelerated recognition of future revenues in the current year (Basu 1997; Bhattacharaya, Daouk, and Welker 2003). This finding implies a possible method of earnings management in relation to the matching principle if managerial opportunistic incentives exist.

\subsection{Hypothesis Development}

Factors that affect the matching principle include inevitable business environments, uncertainties in economic circumstances, managerial discretion, and changes in the accounting regulation system (Donelson, Jennings, and McInnis 2011). Moreover, prior studies of accounting information and its usefulness indicate that firm characteristic variables, such as losses, nonrecurring items, and firm size, affect matching extent and behavior (Collins, Maydew, and Weiss 1997; Francis and Shipper 1999). In a study of firm characteristic variables that affect matching amid changes in accounting environments, Paek (2011a) indicates that losses and discretionary accruals are significantly associated with inappropriate matching. This means that higher loss reporting, depreciation of tangible and intangible assets, and discretionary accruals lead to an increased probability of inappropriate matching. Whereas prior studies focus on understanding the reasons for changes in matching, this study provides an additional contribution by further analyzing the possibility that financial distress and managerial discretion affect matching. On the other hand, many studies find that auditors are more likely to issue GCOs when firms are less profitable, have higher leverage, have lower liquidity, have had a prior GCO and have defaulted on debt (Carson et al. 2013).

In view of the prior literature cited above, we propose that if ambivalent (intertwined phenomena) characteristics of earnings management are observed in firms that receive GCOs, a systematic relationship is likely to be observed based on the financial characteristic variables. Thus, investigating GCO firms' financial reporting characteristics is important in demonstrating a significant relationship between the revenue-expense matching principle and earnings 
management. We expect that if a GCO firm changes its business strategy depending on the level of financial distress and if the results of its financial reporting are affected by the manager's interruption of accounting choices and estimates, those firms may use recognition of current expenses related to current revenues to either aggressively or conservatively account for the firm's level of financial distress; this behavior occurs pursuant to financial characteristic variables such as firm performance, debt to equity ratio, and negative equity. Based on this logic, we hypothesize the following:

H1: Firms with GCOs will both delay and accelerate recognition of current expenses for current revenues.

In general firms that receive GCOs are financially distressed. In a study of the financial reporting characteristics of GCO firms listed in Korea, Kim (2013) finds that these firms demonstrate income-increasing earnings management through positive $(+)$ discretionary accruals and downward earnings management through extremely negative (-) discretionary accruals. Hyun et al. (2014), who examine the fundamental reasons for worsening scenarios under the matching principle, find that change in interest costs is the main reason for mismatching because of changes in the debt-equity ratio. Recognition of revenues and expenses by firms with GCOs can be delayed or accelerated, depending on firm characteristic variables such as the debt-equity ratio, the return on assets, and impaired capital. Delayed or accelerated recognition of revenues and expenses can affect the financial reporting characteristics of firms that follow this business strategy (Paek 2013). Therefore, firms that receive GCOs are expected, in their entirety, to demonstrate both positive $(+)$ and negative (-) discretionary accruals simultaneously. As such, firms that receive GCOs may exhibit matching with attenuated neutrality owing to recognition of delayed and accelerated current expenses. If firms with GCOs have positive discretionary accruals, this scenario reflects the manipulation of accounting numbers, or aggressive accounting, through recognition of current expenses later. Conversely, if firms that receive GCOs have negative discretionary accruals, this scenario indicates downward earnings, or conservative accounting, through recognition of current expenses earlier. Therefore, we hypothesize the following:

H2: Firms with highly positive (+) discretionary accruals that receive GCOs are associated with aggressive accounting, i.e., recognition of current expenses later, whereas firms with extremely negative (-) discretionary accruals that receive GCOs are associated with conservative accounting, i.e., recognition of current expenses earlier.

For GCO firms that are in relatively less severe financial distress or are characterized by lower firm performance and leverage, incentives may exist to increase earnings, although the increased earnings may raise significant questions amid going-concern uncertainties; these incentives include aggressive accounting to reduce the cost of interest for debt financing, to disguise the prior period's weak firm performance, or to avoid receipt of the same GCO from auditors by recognizing current expenses in a delayed manner. Conversely, if severe financial distress reaches a serious condition, such as impaired capital (i.e., negative equity), loss in earnings or high leverage, a firm has a high probability of becoming insolvent and is on the edge of bankruptcy. Such firms also have a high audit risk of business failure, according to auditors. If the audit risk is high, the prior period's accruals often reverse because of auditors' conservatism (Lu and Sapra 2009), resulting in extremely negative (-) discretionary accruals. An auditor's conservatism may increase asset write-offs and decrease earnings through recognition of current expenses earlier, a scenario that reflects conservative accounting. Based on the above logic, we hypothesize the following:

H3: Firms in more severe financial distress that receive GCOs are more likely to adopt conservative accounting, i.e., recognize current expenses earlier, whereas firms with less financial distress that receive GCOs are more likely to adopt aggressive accounting, i.e., recognize current expenses later.

\section{RESEARCH DESIGN AND SAMPLE SELECTION}

\subsection{Research Design}

\subsubsection{Controlling for Potential Sample-Selection Bias and Endogeneity of GCO Firms}

An auditor's decision to express a GCO is not random but depends on a firm's characteristics. There is a probability that differences in auditors' personal tendencies or the characteristics of audit firms can affect the test results (Bartov, Gul, and Tsui 2000; Butler, Leone, and Willenborg 2004; Kaplan and Williams 2013). Moreover, because 
of possible endogeneity between discretionary accruals and GCOs, which may lead to simultaneous equation and omitted variables bias, this issue must be controlled. To address the sample-selection bias and endogeneity issues, we use the Heckman (1979) two-stage regression model. We estimate the probability that a firm receives a GCO, using the first-stage model, where firms that receive GCOs are the dependent variable. We estimate the inverse mills ratio $(L a m b d a)$ via the probit model, using firm characteristics as explanatory variables.

In the probit model (1), we include the prior period's absolute discretionary accruals as a control variable because a firm with low earnings quality is likely to have a GCO (Mutchler, Hoopwood, and McKeown 1997). The higher the level of financial distress is, the greater the probability of receiving a GCO is. We also include leverage ( $L E V)$, longterm debt (LTDT), and the change in long-term debt (CLTDT) (Mutchler, Hoopwood, and McKeown 1997); in addition, we use firms with a loss (LOSS) as control variables because such firms have a high risk of business failure. Altman's (1968) Z-score is included as a proxy for the risk of bankruptcy (Mutchler 1985); in addition, cash flow from operations $(C F O)$, cash and cash equivalents $(C A S H)$, and return on assets $(R O A)$ are used as proxies for operational performance and liquidity (Mutchler, Hoopwood, and McKeown 1997; DeFond, Ragunandan, and Subramanyam 2002; Fargher and Jiang 2008). Big 4 is included as a control variable because firms audited by a Big 4 accounting firm have a high probability of receiving a GCO based on a Big 4 audit firm's high auditing quality (DeAngelo 1981). The inverse mills ratio, estimated in the first stage, is included as a control variable in the twostage model used to test the hypotheses.

1st stage:

$$
\begin{aligned}
\operatorname{Probit}\left(G C O_{i t}\right)= & \alpha_{0}+\alpha_{1} A B S_{-} D A_{i t-1}+\alpha_{2} L n S A L E_{i t}+\alpha_{3} L E V_{i t}+\alpha_{4} R O A_{i t}+\alpha_{5} C A S H_{i t} \\
& +\alpha_{6} Z_{i t}+\alpha_{7} C Z_{i t}+\alpha_{8} C F O_{i t}+\alpha_{9} L T D T_{i t}+\alpha_{10} C L T D T_{i t}+\alpha_{11} B I G 4_{i t} \\
& +\alpha_{12} L O S S_{i t}+\varepsilon_{i t}
\end{aligned}
$$

See the Appendix for definitions of the variables.

This study uses Kothari, Leone, and Wasley's (2005) model to estimate discretionary accruals based on the modified Jones (1991) model with reflected firm performance $(R O A)$. Discretionary accruals are measured using the coefficients of model (2), estimated for non-GCO firms by year and industry. The estimated discretionary accruals are then used in model (3) for GCO firms.

$$
\begin{aligned}
& T A_{i t}=c_{1}+c_{2}\left(\Delta S A L E_{i t}-\triangle A R_{i t}\right)+c_{3} P P E_{i t}+c_{4} R O A_{i t}+\varepsilon_{i t} \\
& D A_{i t}=T A_{i t}-\left[\check{\mathrm{c}}_{1}+\check{\mathrm{c}}_{2}\left(\Delta S A L E_{i t}-\Delta A R_{i t}\right)+\check{\mathrm{c}}_{3} P P E_{i t}+\check{\mathrm{c}}_{4} R O A_{i t}\right] \\
& \text { DA (PO_or NE_DA })_{i t}=b_{10}+b_{11} G C O_{i t}+b_{12} L a m b d a+b_{13} S I Z E_{i t}+b_{14} B T M_{i t}+b_{15} L E V_{i t} \\
& +b_{16} C F O_{i t}+b_{17} G R W_{i t}+b_{18} A B S_{-} T A_{i t}+b_{19} Z_{i t}+b_{20} B I G 4_{i t} \\
& +b_{21} L_{O S S_{i t}}+b_{22} R O A_{i t-1}+b_{23} R O \bar{A}_{i t-1}{ }^{2}+\sum I D+\sum Y R+\varepsilon_{i t}
\end{aligned}
$$

See the Appendix for definitions of the variables.

To analyze the relationship between GCOs and discretionary accruals, we formulate model (4) in which the dependent variable is discretionary accruals, and the independent variables are firms that receive GCOs for the current fiscal year's financial statements. We expect that the coefficient $\left(b_{11}\right)$ is significant and positive.

Control variables include audit firm size (SIZE), operating cash flow (CFO), and the debt-to-book value ratio (LEV) (Nah and Choi 2000). We control for size, book to market, and leverage, consistent with Butler, Leone, and Willenborg (2004). Firm size indicates a firm's information environment and is used as a proxy for the various omitted variables (Becker et al. 1998). The debt-to-book value $(L E V)$ is negatively associated with discretionary accruals because a higher debt-to-book value ratio may lead to stronger incentives to engage in earnings management (DeFond and Jiambalvo 1994). Operating cash flow is expected to be negatively related to discretionary accruals (Dechow 1994; DeFond and Subramanyam 1998), whereas the growth rate (GRW) is positively associated with discretionary accruals because growing firms wish to show strong firm performance and sustainable growth. The Altman (1968) Z-score is a summary measure of financial risk, and firms' loss (LOSS) 
signifies higher operating risk. Lagged $R O A$ and $R O A$ squared are included to control for a non-linear relationship between firm performance and discretionary accruals (Butler, Leone, and Willenborg 2004; Kothari, Leone, and Wasley 2005).

\subsubsection{Hypothesis Testing Model}

Dichev and Tang (2008) estimate the degree of matching by regressing prior, current, and next year's expenses on current revenues. The regression coefficients, $\mathrm{a}_{1}, \mathrm{a}_{2}$, and $\mathrm{a}_{3}$, represent the respective degrees of early, neutral, and delayed recognition of expenses in regression model (5). A larger positive $\mathrm{a}_{2}$ denotes a higher degree of matching, which means that the firm exhibits proper matching between current expenses and current revenues. A larger positive $a_{1}$ indicates earlier recognition of current expenses, which is consistent with conservative accounting; and a larger positive $\mathrm{a}_{3}$ indicates delayed recognition of current expenses, which is consistent with aggressive accounting.

$$
\begin{aligned}
R E V_{i t}= & a_{0}+a_{1} E X P_{i t-1}+a_{2} E X P_{i t}+a_{3} E X P_{i t+1}+e_{i t} \\
R E V_{i t}= & a_{10}+a_{11} G C O_{i t}+a_{12} E X P_{i t-1}+a_{13} G C O_{i t} * E X P_{i t-1}+a_{14} E X P_{i t} \\
& +a_{15} G C O_{i t}{ }^{*} E X P_{i t}+a_{16} E X P_{i t+1}+a_{17} G C O_{t} * E X P_{i t+1}+e_{i t}
\end{aligned}
$$

See the Appendix for definitions of the variables.

Equation (6) is used to examine the degree of matching of firms that receive GCOs. In equation (6), variables of interest include the interactions between firms with GCOs and expenses in prior, current, and subsequent years (for which the coefficients are $a_{13}, a_{15}$, and $a_{17}$, respectively). We expect that the coefficient $a_{15}$ for neutral accounting will be significant and negative (-), whereas the coefficients $\mathrm{a}_{13}$ and $\mathrm{a}_{17}$ will be significant and positive (+).

To test hypothesis 2, we divide firms with GCOs into three portfolios by discretionary accruals and determine matching types for firms with the highest and lowest discretionary accruals. We expect that the group with the highest discretionary accruals uses aggressive accounting, i.e., recognizes current expenses in a delayed manner, whereas the group with the lowest accruals uses conservative accounting, i.e., recognizes current expenses earlier, leading to downward earnings management. To determine the types of matching exhibited by firms with GCOs, as indicated by discretionary accruals, we employ regression model (7). We expect that the coefficient $\left(b_{35}\right)$ for the interaction between the lowest discretionary group and prior period expenses $\left(L D A^{*} E X P_{t-1}\right)$ and the coefficient $\left(\mathrm{b}_{40}\right)$ for the interaction between the highest discretionary group and subsequent period expenses $\left(H D A^{*} E X P_{t+l}\right)$ will both be significant and positive $(+)$.

$$
\begin{aligned}
R E V_{t} & =b_{30}+b_{31} H D A_{i t}+b_{32} L D A_{i t}+b_{33} E X P_{i t-1}+b_{34} H D A_{i t} * E X P_{i t-1} \\
& +b_{35} L D A_{i t} * E X P_{i t-1}+b_{36} E X P_{i t}+b_{37} H D A_{i t}{ }^{*} E X P_{i t}+b_{38} L D A_{i t} * E X P_{i t} \\
& +b_{39} E X P_{i t+1}+b_{40} H D A_{i t} * E X P_{i t+1}+b_{41} L D A_{i t} * E X P_{i t+1}+e_{t}
\end{aligned}
$$

See the Appendix for definitions of the variables.

Although firms with GCOs are characterized by the same uncertainty, they may have different financial reporting characteristics owing to differing levels of financial distress. Therefore, we test ways in which the matching of firms that receive GCOs changes, using the debt-equity ratio, firm performance, and negative equity as firms' characteristic variables. To test hypothesis 3, firms with GCOs are divided into three portfolios according to debt-toequity ratio $(L E V)$. Firms with negative equity that receive GCOs are found in the highest debt-to-equity ratio portfolio, which is more severely financially distressed. We use only the highest and lowest portfolios in regression model (8). For GCO firms with the highest debt-to-equity ratios and negative equity, we test the hypothesis that they use conservative accounting. To support hypothesis 3 , coefficients $\mathrm{a}_{34}$ and $\mathrm{a}_{53}$ would be significant and positive ( + ).

To identify less financially distressed firms, firms with GCOs are divided into three portfolios based on firm performance $(R O A)$. We use only the highest and lowest portfolios of firms, as measured by ROA, in regression model (10). The highest leverage firms with negative equity $(N E G E Q)$ indicate more severely financially distressed firms, whereas the lowest performance $(R O A)$ firms indicate less financially distressed firms. For GCO firms with 
the highest and lowest firm performance, we test the hypothesis that firms with the lowest ROAs use aggressive accounting. To support hypothesis 3 , the coefficient $\mathrm{a}_{81}$ would be significant and positive $(+)$.

$$
\begin{aligned}
R E V_{i t} & =a_{30}+a_{31} H L E V_{i t}+a_{32} L L E V_{i t}+a_{33} E X P_{i t-1}+a_{34} H L E V_{t}{ }^{*} E X P_{i t-1} \\
& +a_{35} L L E V^{*} E X P_{i t-1}+a_{36} E X P_{i t}+a_{37} H L E V^{*} E X P_{i t}+a_{38} L L E V_{i t}{ }^{*} E X P_{i t} \\
& +a_{39} E X P_{i t+1}+a_{40} H L E V_{i t}{ }^{*} E X P_{i t+1}+a_{41} L L E V_{i t}{ }^{*} E X P_{i t+1}+e_{i t} \\
R E V_{i t} & =a_{50}+a_{51} N E G E Q_{i t}+a_{52} E X P_{i t-1}+a_{53} N E G E Q_{i t} * E X P_{i t-1}+a_{54} E X P_{i t} \\
& +a_{55} N E G E Q_{i t}{ }^{*} E X P_{i t}+a_{56} E X P_{i t+1}+a_{57} N E G E Q_{i t}{ }^{*} E X P_{i t+1}+e_{i t} \\
& \\
R E V_{i t} & =a_{70}+a_{71} H R O A_{i t}+a_{72} L R O A_{i t}+a_{73} E X P_{i t-1}+a_{74} H R O A_{i t} * E X P_{i t-1} \\
& +a_{75} L R O A^{*} E X P_{i t-1}+a_{76} E X P_{i t-1}+a_{77} H R O A_{i t}{ }^{*} E X P_{i t}+a_{78} L R O A_{i t} * E X P_{i t} \\
& +a_{79} E X P_{i t+1}+a_{80} H_{R O A}{ }^{*} E X P_{i t+1}+a_{81} L R O A_{i t}{ }^{*} E X P_{i t+1}+e_{i t}
\end{aligned}
$$

See the Appendix for definitions of the variables.

\subsection{Sample Selection}

The sample is selected from firms listed on the Korea Stock Exchange (KSE) and the Korea Dealers Automated Quotation (KOSDAQ) during the years 2000 to 2010. Firms that receive GCOs are manually collected from audit reports in the Data Analysis, Retrieval and Transfer (DART) System (http://dart.fss.or.kr). We extract the firms that receive unqualified opinions but have separately identified a GCO in the explanatory paragraph of the external audit reports; these we designate as firms that receive GCOs. Because of differences in the information contents of the other audit opinions, we exclude firms with qualified, adverse, or disclaimer opinions in the audit reports. We also exclude financial firms because they have a different financial data composition than non-financial firms. More specifically, the sample is limited to firms that satisfy the following conditions:

(1) Companies listed on KSE and KOSDAQ of the Korean capital markets,

(2) Non-financial firms, and

(3) Firms for which financial data can be retrieved from KIS-VALUE and the TS-2000 database.

The sample from KSE and KOSDAQ listed firms, excluding financial companies, includes 20,413 firm-year observations. Among these, firms that receive GCOs generate 1,232 firm-year observations during the sample period after excluding firm-years from 1999, the year that auditing standards for GCOs changed. In addition, 2,089 firmyear observations were eliminated because of missing financial data. Because firms that receive GCOs experience extreme financial stress, the distribution of such firms is skewed to one side. To minimize the loss of firms that received audit opinions, we separate firms into two groups: those that received GCOs and those that did not receive GCOs. In addition, we truncate the sample by eliminating outliers that lie beyond the top and bottom $0.5 \%$ of each variable. As a result, 149 firm-year observations of firms with GCOs and 3,860 firm-year observations of firms without GCOs are removed. The final sample includes 1,083 firm-year observations of firms with GCOs and 13,232 firm-year observations of firms without GCOs for a total of 14,315 firm-year observations.

Table 1 shows the composition of firms with GCOs and firms without GCOs by year. The number of GCO firms increased during 2003 and 2004, when accounting reform acts were passed in Korea, and during 2007 and 2008, when the global financial crisis and economic depression set in (Fargher and Jiang 2008; Gramling, Krishnan, and Zhang 2011; Xu et al. 2011). 
Table 1. Firms with GCOs by year

\begin{tabular}{c|c|c|c}
\hline Year & No. of Obs. & Non-GCO firms & GCO firms \\
\hline 2000 & 945 & 881 & 64 \\
\hline 2001 & 1,113 & 1,067 & 66 \\
\hline 2002 & 1,230 & 1,142 & 98 \\
\hline 2003 & 1,327 & 1,210 & 117 \\
\hline 2004 & 1,317 & 1,199 & 118 \\
\hline 2005 & 1,334 & 1,254 & 80 \\
\hline 2006 & 1,377 & 1,283 & 94 \\
\hline 2007 & 1,425 & 1,310 & 115 \\
\hline 2008 & 1,471 & 1,277 & 194 \\
\hline 2009 & 1,394 & 1,296 & 98 \\
\hline 2010 & 1,352 & 1,313 & 39 \\
\hline Total & 14,315 & 13,232 & 1,083 \\
\hline
\end{tabular}

\section{EMPIRICAL RESULTS}

\subsection{Descriptive Statistics}

Panel A of Table 2 provides descriptive statistics for the total sample. Panel B provides descriptive statistics for firms that received GCOs and firms that did not receive GCOs along with the p-values used in t-tests and nonparametric tests of equality between the two groups ( $\mathrm{t}$-test and Wilcoxon signed rank test). There are significant differences with respect to most variables for firms that received GCOs and firms that did not. The means of prior and current expenses are both below 1.0, whereas the mean of next-year expenses is above 1.0, showing low neutrality accounting and delayed recognition of current expenses. Firms with GCOs appear to have higher prior, current, and next-year expenses compared with firms without GCOs. The size (SIZE) of firms with GCOs is smaller, and the growth rates $(G R W)$ and market-to-book value ratios $(B T M)$ are lower for such firms than for firms without GCOs. Whereas cash flow from operations $(C F O)$ of firms with GCOs is significantly low, firm losses $(L O S S)$ and long-term debt (LTDT) are substantially higher than those for firms without GCOs. However, the change in $L T D T$, which is the difference between long-term debt in the prior period and current period, is significantly low, meaning that the long-term debts of firms with GCOs are reduced. This condition aggravates operating cash flow. Moreover, the debt-to-equity ratios of firms with GCOs appear to be high, whereas the Altman Z-scores ( $Z$ ) of firms with GCOs are significantly low, implying that the risk of bankruptcy is high. In other words, the financial stress of firms with GCOs is significantly higher than that of firms without GCOs.

Table 2. Descriptive statistics

\begin{tabular}{lrrrrrrr}
\hline \multicolumn{2}{l}{ Panel A. Total Sample $(\mathrm{n}=14,315)$} & & & & & \\
\hline \multicolumn{1}{c}{ Variable } & Mean & Median & Std & Min & Q1 & Q3 & Max \\
\hline$R E V_{t}$ & 1.001 & 0.937 & 0.713 & 0.000 & 0.607 & 1.313 & 24.490 \\
\hline$E X P_{t+1}$ & 1.071 & 0.968 & 0.585 & 0.006 & 0.695 & 1.307 & 23.915 \\
\hline$E X P_{t}$ & 0.985 & 0.920 & 0.705 & 0.000 & 0.614 & 1.278 & 30.326 \\
\hline$E X P_{t-1}$ & 0.985 & 0.921 & 0.786 & 0.000 & 0.606 & 1.287 & 38.972 \\
\hline$D A$ & -0.001 & 0.005 & 0.108 & -4.215 & -0.055 & 0.060 & 3.954 \\
\hline$S I Z E$ & 18.274 & 18.069 & 1.338 & 13.350 & 17.344 & 18.986 & 23.728 \\
\hline$C F O$ & 0.036 & 0.045 & 0.135 & -1.994 & -0.018 & 0.107 & 0.689 \\
\hline$R O A$ & 0.040 & 0.047 & 0.120 & -1.491 & 0.006 & 0.097 & 0.496 \\
\hline$B I G 4$ & 0.476 & 0.000 & 0.499 & 0.000 & 0.000 & 1.000 & 1.000 \\
\hline$L E V$ & 1.151 & 0.746 & 3.641 & -55.430 & 0.373 & 1.335 & 45.192 \\
\hline$Z$ & 2.648 & 2.388 & 3.104 & -45.990 & 1.528 & 3.490 & 69.183 \\
\hline$G R W$ & 0.171 & 0.064 & 8.046 & -4.580 & -0.055 & 0.192 & 91.396 \\
\hline$C A S H$ & 0.074 & 0.045 & 0.087 & 0.000 & 0.016 & 0.099 & 1.201 \\
\hline$L T D T$ & 0.051 & 0.014 & 0.127 & 0.000 & 0.000 & 0.064 & 8.220 \\
\hline$L O S S$ & 0.265 & 0.000 & 0.441 & 0.000 & 0.000 & 1.000 & 1.000 \\
\hline
\end{tabular}

(Table 2 continued on next page) 
(Table 2 continued)

\begin{tabular}{|c|c|c|c|c|c|c|c|c|c|c|}
\hline \multicolumn{11}{|c|}{ Panel B. Sample by GCO $(n=1,083)$ and non-GCO $(n=13,232)$} \\
\hline Variable & Group & Mean & Median & Std & Min & Q1 & Q3 & Max & t-stat. & $\begin{array}{c}\text { Wilcoxon } \\
\text { z-stat. }\end{array}$ \\
\hline \multirow{2}{*}{$R E V_{t}$} & GCO & 0.802 & 0.625 & 1.499 & 0.000 & 0.332 & 0.959 & 30.065 & \multirow{2}{*}{$-9.17^{* * *}$} & \multirow{2}{*}{$-17.80^{* * *}$} \\
\hline & Non-GCO & 1.019 & 0.965 & 0.651 & 0.000 & 0.641 & 1.336 & 12.758 & & \\
\hline \multirow{2}{*}{$E X P_{t+1}$} & $\mathrm{GCO}$ & 1.258 & 1.070 & 1.010 & 0.006 & 0.741 & 1.523 & 23.915 & \multirow{2}{*}{$-11.03^{* * *}$} & \multirow{2}{*}{$-7.80^{* * *}$} \\
\hline & Non-GCO & 1.056 & 0.960 & 0.532 & 0.015 & 0.692 & 1.292 & 4.811 & & \\
\hline \multirow{2}{*}{$E X P_{t}$} & GCO & 1.118 & 0.949 & 1.359 & 0.000 & 0.650 & 1.330 & 30.326 & \multirow{2}{*}{$-6.48^{* * *}$} & \multirow{2}{*}{$-2.65^{* * *}$} \\
\hline & Non-GCO & 0.974 & 0.917 & 0.621 & 0.000 & 0.612 & 1.273 & 12.675 & & \\
\hline \multirow{2}{*}{$E X P_{t-1}$} & GCO & 1.109 & 0.927 & 1.692 & 0.000 & 0.610 & 1.337 & 38.972 & \multirow{2}{*}{$-5.31^{* * *}$} & \multirow{2}{*}{-1.54} \\
\hline & Non-GCO & 0.974 & 0.921 & 0.653 & 0.000 & 0.605 & 1.283 & 12.675 & & \\
\hline \multirow{2}{*}{$D A$} & GCO & -0.014 & 0.048 & 0.571 & -4.215 & -0.161 & 0.215 & 3.954 & \multirow{2}{*}{$2.36^{* *}$} & \multirow{2}{*}{$7.15^{* * *}$} \\
\hline & Non-GCO & -0.001 & 0.004 & 0.108 & -1.062 & -0.052 & 0.055 & 0.774 & & \\
\hline \multirow{2}{*}{ SIZE } & $\mathrm{GCO}$ & 17.351 & 17.265 & 1.201 & 13.350 & 16.627 & 17.860 & 22.705 & \multirow{2}{*}{$24.07^{* * *}$} & \multirow{2}{*}{$25.15^{* * *}$} \\
\hline & Non-GCO & 18.410 & 18.184 & 1.298 & 15.447 & 17.497 & 19.080 & 23.728 & & \\
\hline \multirow{2}{*}{$\mathrm{CFO}$} & GCO & -0.160 & -0.101 & 0.249 & -1.994 & -0.243 & -0.008 & 0.689 & \multirow{2}{*}{$54.61^{* * *}$} & \multirow{2}{*}{$36.29^{* * *}$} \\
\hline & Non-GCO & 0.052 & 0.051 & 0.103 & -0.487 & -0.005 & 0.111 & 0.496 & & \\
\hline \multirow{2}{*}{$R O A$} & GCO & -0.179 & -0.143 & 0.202 & -1.491 & -0.261 & -0.045 & 0.263 & \multirow{2}{*}{$72.93^{* * *}$} & \multirow{2}{*}{$44.90^{* * *}$} \\
\hline & Non-GCO & 0.054 & 0.049 & 0.088 & -0.405 & 0.013 & 0.098 & 0.496 & & \\
\hline \multirow{2}{*}{$B I G 4$} & GCO & 0.321 & 0.000 & 0.467 & 0.000 & 0.000 & 1.000 & 1.000 & \multirow{2}{*}{$10.62^{* * *}$} & \multirow{2}{*}{$10.57^{* * *}$} \\
\hline & Non-GCO & 0.498 & 0.000 & 0.500 & 0.000 & 0.000 & 1.000 & 1.000 & & \\
\hline & GCO & 3.168 & 1.377 & 12.002 & -55.430 & 0.338 & 3.499 & 45.192 & $* *$ & 1281 \\
\hline LEV & Non-GCO & 0.962 & 0.712 & 1.013 & -7.875 & 0.366 & 1.248 & 26.957 & & -12 \\
\hline 7 & $\mathrm{GCO}$ & -1.841 & -1.008 & 5.085 & -45.990 & -3.523 & 0.448 & 69.183 & $5425^{* * *}$ & $1785^{* * *}$ \\
\hline$Z$ & Non-GCO & 3.050 & 2.526 & 2.583 & -4.063 & 1.737 & 3.657 & 36.800 & & 47.85 \\
\hline$G P W$ & GCO & -0.042 & -0.160 & 1.749 & -4.580 & -0.532 & 0.105 & 39.531 & $1087^{* * *}$ & $2053^{* * *}$ \\
\hline$G R W$ & Non-GCO & 0.186 & 0.070 & 8.458 & -2.654 & -0.038 & 0.192 & 91.396 & 10.87 & 20.53 \\
\hline & GCO & 0.055 & 0.017 & 0.109 & 0.000 & 0.004 & 0.054 & 1.201 & & 173 \\
\hline CASH & Non-GCO & 0.074 & 0.048 & 0.082 & 0.000 & 0.018 & 0.100 & 0.635 & & 17.3 \\
\hline & GCO & 0.101 & 0.003 & 0.379 & 0.000 & 0.000 & 0.063 & 8.220 & & 30 \\
\hline$L T D T$ & Non-GCO & 0.044 & 0.013 & 0.069 & 0.000 & 0.000 & 0.061 & 0.997 & & \\
\hline$I O S C$ & GCO & 0.917 & 1.000 & 0.276 & 0.000 & 1.000 & 1.000 & 1.000 & $5570^{* * *}$ & $5056^{* * *}$ \\
\hline LOSS & Non-GCO & 0.221 & 0.000 & 0.415 & 0.000 & 0.000 & 0.000 & 1.000 & -55.79 & -50.56 \\
\hline
\end{tabular}

\subsection{Correlation Analysis}

The upper right section of Table 3 shows Pearson correlations, and the lower left section indicates Spearman correlations. Correlations between firm size (SIZE) and prior and current expenses are significant and negative (-), showing that larger firms tend to delay recognition of current expenses on current revenues. The correlation between recognition of expenses in the following period and firm size is insignificant. Early recognition of current expenses and GCO firms are significantly and positively correlated. There is a significantly negative correlation between GCO firms and Altman (1968) Z-scores $(Z)$, which represent the bankruptcy index, so that firms facing severe financial distress have a higher probability of receiving GCOs. The Pearson (Spearman's) correlation between firms with GCOs and neutral recognition is significantly positive although relatively low, with a value of $0.054(0.022)$, as is that between firms with GCOs and delayed recognition of current expenses, with a value of 0.046 (0.023). 
Table 3. Correlation analysis (Pearson/Spearman)

\begin{tabular}{|c|c|c|c|c|c|c|c|c|c|c|c|c|c|}
\hline & $D A$ & GCO & $R E V$ & $E X P_{t-1}$ & $E X P_{t}$ & $E X P_{t+1}$ & SIZE & BTM & $L E V$ & $Z$ & GRW & $L T D T$ & LOSS \\
\hline$D A$ & 1 & $\begin{array}{c}-0.019 \\
(0.018) \\
\end{array}$ & $\begin{array}{c}0.203 \\
(<.0001)\end{array}$ & $\begin{array}{c}-0.099 \\
(<.0001)\end{array}$ & $\begin{array}{c}0.153 \\
(<.0001)\end{array}$ & \begin{tabular}{|c|}
0.180 \\
$(<.0001)$
\end{tabular} & $\begin{array}{c}0.057 \\
(<.0001)\end{array}$ & $\begin{array}{c}0.033 \\
(0.000) \\
\end{array}$ & \begin{tabular}{|c|}
0.011 \\
$(0.171))$ \\
\end{tabular} & \begin{tabular}{|c|}
0.211 \\
$(<.0001)$
\end{tabular} & & & \\
\hline$C O$ & $\mid \begin{array}{c}0.059 \\
(<.0001)\end{array}$ & 1 & $\begin{array}{c}-0.076 \\
(<.0001)\end{array}$ & $\begin{array}{c}0.091 \\
(<.0 .001)\end{array}$ & $\begin{array}{c}0.054 \\
(<.0001)\end{array}$ & $\begin{array}{c}0.046 \\
(<.0001)\end{array}$ & \begin{tabular}{|c|}
-0.197 \\
$(<.0001)$
\end{tabular} & \begin{tabular}{|c|}
-0.078 \\
$(<.0001)$
\end{tabular} & $\begin{array}{c}0.162 \\
(<.0001)\end{array}$ & \begin{tabular}{|c|}
-0.413 \\
$(<.0001)$
\end{tabular} & $\begin{array}{c}-0.007 \\
(0.381)\end{array}$ & $\begin{array}{c}0.113 \\
(<.0001)\end{array}$ & $\begin{array}{c}0.422 \\
(<.0001)\end{array}$ \\
\hline$F V$ & $\begin{array}{l}-0.010 \\
(0.200)\end{array}$ & $\begin{array}{c}-0.148 \\
(<.0001)\end{array}$ & 1 & $\begin{array}{c}0.618 \\
(<.0 .001)\end{array}$ & $\begin{array}{c}0.914 \\
<.0001)\end{array}$ & $\begin{array}{c}0.667 \\
(<.0001)\end{array}$ & $\begin{array}{c}0.030 \\
(0.000)\end{array}$ & $\begin{array}{l}-0.010 \\
(0.277)\end{array}$ & & $\begin{array}{c}0.149 \\
(<.0001)\end{array}$ & \begin{tabular}{|c|}
-0.019 \\
$(0.027)$
\end{tabular} & \begin{tabular}{|c|}
-0.063 \\
$(<.0001)$
\end{tabular} & \begin{tabular}{|c|}
-0.103 \\
$(<.0001)$
\end{tabular} \\
\hline$X P$ & $\begin{array}{c}-0.083 \\
(<.0001) \\
\end{array}$ & $\begin{array}{c}0.065 \\
(<.0001) \\
\end{array}$ & $\begin{array}{c}0.617 \\
(<.0001)\end{array}$ & 11 & $\begin{array}{c}0.667 \\
(<.0001)\end{array}$ & $\begin{array}{c}0.603 \\
(<.0001)\end{array}$ & $\begin{array}{c}-0.096 \\
(<.0001) \\
\end{array}$ & & & $\begin{array}{c}-0.01 \\
(<.0001)\end{array}$ & & & \\
\hline$E X P_{t}$ & \begin{tabular}{|c|}
-0.011 \\
$(0.179)$ \\
\end{tabular} & $\begin{array}{c}0.022 \\
(0.008) \\
\end{array}$ & $\begin{array}{c}0.931 \\
(<.0001)\end{array}$ & $\begin{array}{c}0.671 \\
(<.0001) \\
\end{array}$ & 1 & \begin{tabular}{|c|}
0.725 \\
$(<.0001)$ \\
\end{tabular} & & & & & & & \\
\hline$Y P$ & $\begin{array}{c}0.023 \\
(0.007)\end{array}$ & $\begin{array}{c}0.013 \\
(0.124)\end{array}$ & $\begin{array}{c}0.599 \\
(<.0001)\end{array}$ & $\begin{array}{c}0.583 \\
(<.0001)\end{array}$ & $\begin{array}{c}0.643 \\
(<.0001)\end{array}$ & 1 & $\begin{array}{c}0.010 \\
(0.221)\end{array}$ & \begin{tabular}{|l}
-0.007 \\
$(0.449)$
\end{tabular} & \begin{tabular}{|c|}
0.008 \\
$(0.307)$
\end{tabular} & $\begin{array}{c}0.041 \\
(<.0001)\end{array}$ & \begin{tabular}{|c|}
-0.010 \\
$(0.236)$
\end{tabular} & \begin{tabular}{|c|}
-0.057 \\
$(<.0001)$
\end{tabular} & \\
\hline$I 7 F$ & $\begin{array}{c}0.022 \\
(0.007) \\
\end{array}$ & $\begin{array}{c}-0.210 \\
(<.0001) \\
\end{array}$ & $\begin{array}{c}0.053 \\
(<.0001)\end{array}$ & $\begin{array}{c}-0.099 \\
(<.0001) \\
\end{array}$ & & \begin{tabular}{|c|}
0.009 \\
$(0.269)$ \\
\end{tabular} & 1 & & $\begin{array}{c}0.058 \\
(<.0001) \\
\end{array}$ & \begin{tabular}{|c|c|}
0.057 \\
$(<.0001)$ \\
\end{tabular} & & & \\
\hline$T M$ & $\begin{array}{c}0.057 \\
(<.0001) \\
\end{array}$ & $\begin{array}{c}-0.068 \\
(<.0001) \\
\end{array}$ & $\begin{array}{c}-0.087 \\
(<.0001) \\
\end{array}$ & $\begin{array}{c}-0.026 \\
(0.004) \\
\end{array}$ & $\begin{array}{c}-0.084 \\
(<.0001) \\
\end{array}$ & \begin{tabular}{|c|}
-0.075 \\
$(<.0001)$ \\
\end{tabular} & \begin{tabular}{|c|}
0.163 \\
$(<.0001)$ \\
\end{tabular} & 1 & \begin{tabular}{|c|}
0.046 \\
$(<.0001)$ \\
\end{tabular} & \begin{tabular}{|c|}
-0.016 \\
$(0.090)$ \\
\end{tabular} & & \begin{tabular}{|c|}
-0.184 \\
$(<.0001)$ \\
\end{tabular} & \\
\hline$V$ & \begin{tabular}{|c|}
0.013 \\
$(0.116)$ \\
\end{tabular} & $\begin{array}{c}0.107 \\
(<.0001) \\
\end{array}$ & $\begin{array}{c}0.096 \\
(<.0001) \\
\end{array}$ & $\begin{array}{c}0.254 \\
(<.0001) \\
\end{array}$ & $\begin{array}{c}0.160 \\
(<.0001) \\
\end{array}$ & \begin{tabular}{|c|}
0.141 \\
$(<.0001)$ \\
\end{tabular} & \begin{tabular}{|c|}
0.189 \\
$(<.0001)$ \\
\end{tabular} & \begin{tabular}{|c|}
0.076 \\
$(<.0001)$ \\
\end{tabular} & 1 & \begin{tabular}{|c|}
-0.105 \\
$(<.0001)$ \\
\end{tabular} & $\begin{array}{c}0.000 \\
(0.992) \\
\end{array}$ & \begin{tabular}{|c|}
0.079 \\
$(<.0001)$ \\
\end{tabular} & \begin{tabular}{|c|}
0.098 \\
$(<.0001)$ \\
\end{tabular} \\
\hline$Z$ & $\begin{array}{c}0.063 \\
(<.0001) \\
\end{array}$ & $\begin{array}{c}-0.399 \\
(<.0001) \\
\end{array}$ & $\begin{array}{c}0.312 \\
(<.0001)\end{array}$ & $\begin{array}{c}0.162 \\
(<.0001) \\
\end{array}$ & $\begin{array}{c}0.158 \\
(<.0001) \\
\end{array}$ & \begin{tabular}{|c|}
0.137 \\
$(<.0001)$ \\
\end{tabular} & $\begin{array}{c}0.004 \\
(0.593) \\
\end{array}$ & $\begin{array}{c}-0.427 \\
(<.0001) \\
\end{array}$ & \begin{tabular}{|c|}
-0.468 \\
$(<.0001)$ \\
\end{tabular} & 1 & \begin{tabular}{|c|}
-0.000 \\
$(0.980)$ \\
\end{tabular} & \begin{tabular}{|c|}
-0.210 \\
$(<.0001)$ \\
\end{tabular} & \begin{tabular}{|c|}
-0.384 \\
$(<.0001)$ \\
\end{tabular} \\
\hline$G R D$ & \begin{tabular}{|l|}
-0.008 \\
$(0.341)$ \\
\end{tabular} & $\begin{array}{c}-0.180 \\
(<.0001) \\
\end{array}$ & $\begin{array}{c}-0.042 \\
(<.0001) \\
\end{array}$ & $\begin{array}{c}0.180 \\
(<.0001) \\
\end{array}$ & $\begin{array}{c}-0.086 \\
(<.0001) \\
\end{array}$ & \begin{tabular}{|c|}
-0.046 \\
$(<.0001)$ \\
\end{tabular} & \begin{tabular}{|c|}
0.064 \\
$(<.0001)$ \\
\end{tabular} & \begin{tabular}{|c|}
-0.115 \\
$(<.001)$ \\
\end{tabular} & \begin{tabular}{|c|}
0.038 \\
$(<.0001)$ \\
\end{tabular} & $\begin{array}{c}0.240 \\
(<.0001) \\
\end{array}$ & 1 & \begin{tabular}{|c|}
-0.003 \\
$(0.671)$ \\
\end{tabular} & \begin{tabular}{|c|}
-0.013 \\
$(0.114)$ \\
\end{tabular} \\
\hline$D T$ & \begin{tabular}{|c|}
0.032 \\
$(0.001)$ \\
\end{tabular} & $\begin{array}{c}-0.032 \\
(<.0001) \\
\end{array}$ & $\begin{array}{c}-0.035 \\
(<.0001) \\
\end{array}$ & $\begin{array}{l}-0.000 \\
(0.976) \\
\end{array}$ & $\begin{array}{c}-0.047 \\
(<.0001) \\
\end{array}$ & \begin{tabular}{|c|}
-0.048 \\
$(<.0001)$ \\
\end{tabular} & \begin{tabular}{|c|}
0.102 \\
$(<.0001)$ \\
\end{tabular} & \begin{tabular}{|c|}
0.092 \\
$(<.0001)$ \\
\end{tabular} & \begin{tabular}{|c|}
0.426 \\
$(<.0001)$ \\
\end{tabular} & $\begin{array}{c}-0.227 \\
(<.0001) \\
\end{array}$ & \begin{tabular}{|c|}
0.081 \\
$(<.0001)$ \\
\end{tabular} & 1 & \begin{tabular}{|c|}
0.048 \\
$(<.0001)$ \\
\end{tabular} \\
\hline DSS & $\begin{array}{c}-0.136 \\
(<.0001) \\
\end{array}$ & $\begin{array}{c}0.422 \\
(<.0001) \\
\end{array}$ & $\begin{array}{c}-0.164 \\
(<.0001) \\
\end{array}$ & $\begin{array}{l}-0.029 \\
(0.000)\end{array}$ & $\begin{array}{l}-0.079 \\
(0.032) \\
\end{array}$ & \begin{tabular}{|c|}
-0.014 \\
$(0.101)$ \\
\end{tabular} & \begin{tabular}{|c|}
-0.208 \\
$(<.0001)$ \\
\end{tabular} & \begin{tabular}{|c|}
-0.045 \\
$(<.0001)$ \\
\end{tabular} & \begin{tabular}{|c|}
0.151 \\
$(<.0001)$ \\
\end{tabular} & \begin{tabular}{c|}
-0.532 \\
$(<.0001)$ \\
\end{tabular} & \begin{tabular}{|c|}
-0.287 \\
$(<.0001)$ \\
\end{tabular} & \begin{tabular}{|c|}
-0.041 \\
$(<.0001)$ \\
\end{tabular} & 1 \\
\hline
\end{tabular}

1) The numbers above (below) the diagonal are Pearson (Spearman) correlation coefficients. p-value are in parentheses.

2) See the Appendix for definitions of the variables.

\subsection{Multivariate Regression Model}

\subsubsection{Type of Matching of Revenues and Expenses for GCO Firms}

Table 4 reports the results of matching for GCO firms, as estimated using Dichev and Tang's (2008) model. The coefficient for the interaction between GCO firms and prior-period expenses (early recognition of current expenses) is 0.277 , and the coefficient for the interaction between these firms and following-period expenses is 0.087 ; both results are positive and significant at the $1 \%$ level. Additionally, there is a significant and negative relationship between neutral accounting of firms with GCOs and current revenues (-0.463), with a significance level of $1 \%$. This result suggests that these firms have a tendency towards low neutrality. In other words, firms with GCOs are expected, in their entirety, to simultaneously adopt conservative accounting that recognizes current expenses in an early manner and aggressive accounting that recognizes current expenses in a delayed manner. This finding further implies that such firms have different financial reporting characteristics that reflect their own financial conditions. 
Table 4. Revenue-expense matching and GCO firms

\begin{tabular}{|c|c|c|c|}
\hline $\begin{aligned} & R E V_{i t}=a_{0}+a \\
&+a_{6} E X P \\
&\end{aligned}$ & $X P_{i t-1}+a_{4} E X I$ & & (6) \\
\hline Variable & Coefficient & (t-stat.) & \\
\hline Intercept & $0.050 * * *$ & (7.97) & \\
\hline$G C O_{i t}$ & $-0.454 * * *$ & $(-19.34)$ & \\
\hline$E X P_{i t-1}$ & -0.000 & $(-0.02)$ & \\
\hline$G C O_{i t} * E X P_{t-1}$ & $0.277 * * *$ & (21.59) & \\
\hline$E X P_{i t}$ & 0.998 & $(91.03)$ & \\
\hline $\boldsymbol{G C} \boldsymbol{O}_{i t}{ }^{*} \boldsymbol{E X} \boldsymbol{P}_{i t}$ & $-0.463 * * *$ & $(-26.60)$ & \\
\hline$E X P_{i t+1}$ & 0.013 & $(1.23)$ & \\
\hline$G C O_{i t}{ }^{*} E X P_{i t+1}$ & $0.087 * * *$ & $(5.06)$ & \\
\hline No. of Obs. & \multicolumn{2}{|c|}{14,315} & \\
\hline F statistics & \multicolumn{2}{|c|}{6,299} & \\
\hline Adj. $\mathrm{R}^{2}$ & \multicolumn{2}{|c|}{0.803} & \\
\hline
\end{tabular}

\subsubsection{Type of Matching of Firms that Receive GCOS Depending on the Level of Discretionary Accruals}

Table 5 depicts the results of matching GCO firms within the highest and lowest portfolios. As expected, the coefficient for the group with the lowest discretionary accruals $\left(L D A^{*} E X P_{t-1}\right)$ is significant and positive $(+)$, with a value of 0.231 ; this result indicates that this group may use early recognition of current expenses on current revenues (i.e., conservative accounting) or downward earnings management. Conversely, the coefficient for the group with the highest discretionary accruals is 0.039 , which is positive $(+)$ and marginally significant at the $10 \%$ level, implying that this group may choose aggressive accounting. This result is consistent with hypothesis 2 , which suggests that GCO firms with the highest positive $(+)$ discretionary accruals are associated with aggressive accounting through recognition of current expenses later; however, firms with the lowest negative (-) discretionary accruals are associated with conservative accounting through recognition of current expenses.

Table 5. Matching of firms with GCOs with the highest and lowest discretionary accruals

\begin{tabular}{|c|c|c|}
\hline \multicolumn{3}{|c|}{$\begin{aligned} R E V_{t} & =b_{30}+b_{31} H D A_{i t}+b_{32} L D A_{i t}+b_{33} E X P_{i t-1}+b_{34} H D A_{i t} * E X P_{i t-1} \\
& +b_{35} L D A_{i t} * E X P_{i t-1}+b_{36} E X P_{i t}+b_{37} H D A_{i t} * E X P_{i t}+b_{38} L D A_{i t} * E X P_{i t} \\
& +b_{39} E X P_{i t+1}+b_{40} H D A_{i t} * E X P_{i t+1}+b_{41} L D A_{i t} * E X P_{i t+1}+e_{t}\end{aligned}$} \\
\hline \multirow{2}{*}{ Variable } & \multicolumn{2}{|c|}{ REV } \\
\hline & Coefficient & (t-stat.) \\
\hline Intercept & $-0.173^{* *}$ & $(-2.54)$ \\
\hline$H D A_{i t}$ & 0.018 & $(0.15)$ \\
\hline$L D A_{i t}$ & $0.362 * *$ & $(2.44)$ \\
\hline$E X P_{i t-1}$ & $0.362 * *$ & $(2.57)$ \\
\hline$H D A_{i t} * E X P_{i t-1}$ & -0.058 & $(-0.69)$ \\
\hline$L D A_{i t}{ }^{*} E X P_{i t-1}$ & $0.231 * *$ & (2.32) \\
\hline$E X P_{i t}$ & $0.755^{* * *}$ & $(9.85)$ \\
\hline$H D A_{i t} * E X P_{i t}$ & -0.068 & $(-0.52)$ \\
\hline$L D A_{i t} * E X P_{i t}$ & $-0.652 * * *$ & $(-6.26)$ \\
\hline$E X P_{i t+1}$ & 0.027 & $(0.40)$ \\
\hline$H D A_{i t} * E X P_{i t+1}$ & $0.039 *$ & (1.61) \\
\hline$L D A_{i t}{ }^{*} E X P_{i t+1}$ & 0.050 & $(0.48)$ \\
\hline No. of Obs. & \multicolumn{2}{|c|}{1,083} \\
\hline F statistics & \multicolumn{2}{|c|}{185.07} \\
\hline Adj. $R^{2}$ & \multicolumn{2}{|c|}{0.667} \\
\hline
\end{tabular}




\subsubsection{Conservative Accounting of GCO Firms Through the Matching Principle}

Table 4 shows that conservative or aggressive accounting is applied to the same firms with GCOs. This result indicates that firms with the same uncertainty of continuing as a going-concern may report their financial performances differently according to the level of firms' financial distress. Therefore, it is necessary to analyze how the matching principle differs depending on the debt-to-equity ratio ( $L E V)$, negative equity $(N E G E Q)$, and firm performance $(R O A)$ as financial characteristics variables. This study partitions the full sample by debt-to-equity ratio and firm performance into three portfolios and then uses the highest and lowest portfolios as dummy variables in the regression.

Table 6 indicates the results of the matching principle for firms with GCOs in the highest and lowest portfolios partitioned by debt-to-equity ratio. In addition, the table depicts the relationship between current revenues and prior, current- and following-period recognition of expenses for GCO firms with negative equity (i.e., impaired capital) and losses (i.e., negative ROA). Both the highest and lowest groups exhibit low neutrality in accounting, which is similar to the results presented in Table 4 . However, the coefficient for early recognition of current expenses for the highest debt-to-equity portfolio is significant and positive $(+)$, whereas the coefficient for neutral recognition is significantly negative (-), which indicates low neutral accounting. This result supports hypothesis 3 , suggesting the existence of income-decreasing earnings management via conservative accounting that recognizes current expenses in an accelerated manner. Conversely, the coefficient for the interaction between delayed recognition of current expenses and a high debt-to-equity ratio is insignificantly related to current revenues. These firms are in serious financial trouble with regard to negative equity and loss, which may increase the risk of firm failure and result in a conservative audit (Lu and Sapra 2009). An auditor's conservative approach may prevent a manager's intended intervention in accounting choices. Consequently, these firms exhibit conservative accounting that recognizes current expenses early. The coefficient for the interaction between prior-period expenses and negative equity $\left(N E G E Q^{*} E X P_{t-1}\right)$ of firms with GCOs is $0.495(\mathrm{t}=4.95)$, which is positive $(+)$ and significant at the $1 \%$ level. The coefficient for the interaction between prior period expenses and negative equity (NEGROA*EXP $\left.{ }_{t-1}\right)$ of GCO firms is $0.166(\mathrm{t}=1.98)$, which is positive $(+)$ and significant at the $5 \%$ level. This result is also consistent with hypothesis 3 , implying that conservative accounting that recognizes current expenses early is applied to GCO firms with impaired capital or losses. Conversely, firms with negative equity that receive GCOs may attempt mass asset disposal (Kim, Sin, and Lee 2014); in addition, such firms are more likely to be involved in default on the redemption of debt, delisting, and designation of investment consideration. ${ }^{4}$

\footnotetext{
${ }^{4}$ Test results are not tabulated; however, the probability of default or delisting, as indicated by the coefficients for negative equity firms, are 0.816 and 0.395 , respectively, both of which are positive $(+)$ and significant at the $1 \%$ level.
} 
Table 6. Conservative accounting of firms received GCOs with financial characteristic variables through matching principle

\begin{tabular}{|c|c|c|c|c|c|c|}
\hline \multirow{2}{*}{ Variable } & \multicolumn{2}{|c|}{ REV } & \multicolumn{2}{|c|}{ REV } & \multicolumn{2}{|c|}{ REV } \\
\hline & Coefficient & (t-stat) & Coefficient & (t-stat) & Coefficient & (t-stat) \\
\hline Intercept & $-0.229 * *$ & $(-2.15)$ & $-0.208 * * *$ & $(-3.18)$ & -0.003 & $(-0.04)$ \\
\hline$H L E V_{i t}$ & 0.051 & $(0.49)$ & & & & \\
\hline$L L E V_{i t}$ & $0.354 * *$ & $(2.03)$ & & & & \\
\hline$N E G E Q_{i t}$ & & & $0.280 * *$ & $(1.93)$ & & \\
\hline$N E G R O A_{i t}$ & & & & & 0.008 & $(0.07)$ \\
\hline$E X P_{i t-1}$ & 0.067 & $(0.81)$ & $0.187 * *$ & $(2.54)$ & 0.021 & $(0.26)$ \\
\hline$H L E V_{i t}^{*} E X P_{i t-1}$ & $0.221 * *$ & $(2.16)$ & & & & \\
\hline$L L E V_{i t}{ }^{*} E X P_{i t-1}$ & 0.002 & $(0.98)$ & & & & \\
\hline$N E G E Q * E X P_{i t-1}$ & & & $0.495 * * *$ & (4.95) & & \\
\hline$N E G R O A * E X P_{i t-1}$ & & & & & $0.166 * *$ & (1.98) \\
\hline$E X P_{t}$ & $0.865 * * *$ & $(9.29)$ & $0.632 * * *$ & $(7.33)$ & $0.966^{* * *}$ & $(8.90)$ \\
\hline$H L E V_{i t}{ }^{*} E X P_{i t}$ & $-0.412 * * *$ & $(-3.38)$ & & & & \\
\hline$L L E V_{i t} * E X P_{i t}$ & $-0.409 * * *$ & $(-2.92)$ & & & & \\
\hline$N E G E Q^{*} E X P_{i t}$ & & & $-0.534 * * *$ & $(-4.27)$ & & \\
\hline$N E G R O A * E X P_{i t}$ & & & & & $-0.576^{* * *}$ & $(-4.88)$ \\
\hline$E X P_{i t+1}$ & 0.045 & $(0.50)$ & $0.104 * *$ & $(2.33)$ & -0.003 & $(-0.66)$ \\
\hline$H L E V_{i t}{ }^{*} E X P_{i t+1}$ & 0.129 & $(1.13)$ & & & & \\
\hline$L L E V_{i t}{ }^{*} E X P_{i t+1}$ & -0.032 & $(-0.27)$ & & & & \\
\hline$N E G E Q^{*} E X P_{i t+1}$ & & & -0.133 & $(-1.27)$ & & \\
\hline$N E G R O A * E X P_{i t+1}$ & & & & & 0.067 & $(0.95)$ \\
\hline No. of Obs. & \multicolumn{2}{|c|}{940} & \multicolumn{2}{|c|}{1,083} & \multicolumn{2}{|c|}{1,083} \\
\hline F statistics & \multicolumn{2}{|c|}{118.58} & \multicolumn{2}{|c|}{277.45} & \multicolumn{2}{|c|}{296.05} \\
\hline Adj. $\mathrm{R}^{2}$ & \multicolumn{2}{|c|}{0.579} & \multicolumn{2}{|c|}{0.659} & \multicolumn{2}{|c|}{0.671} \\
\hline
\end{tabular}

1) ***, ** and * denote statistical significance at the 1,5 and 10 percent levels in a two-tailed test, respectively.

2) See the Appendix for definitions of the variables.

\subsubsection{Aggressive Accounting of GCO Firms Within the Lowest ROA Portfolio}

Table 7 provides the results of an analysis employing firm performance in the same manner as the debt-to-equity ratio was employed above. The results show that GCO firms within the highest firm performance portfolio have insignificant coefficients for the neutral, accelerated, or delayed recognition of current expenses, whereas GCO firms with low firm performance have positive $(+)$ and significant coefficients for the delayed recognition of current expenses and a low neutrality in accounting. The coefficient for the interaction between subsequent-period expenses and lowest firm performance $\left(L R O A^{*} E X P_{t+1}\right)$ is 0.64 , which is positive $\left.{ }^{+}\right)$and significant at the $1 \%$ level. This result supports hypothesis 3, implying that GCO firms with poor financial performance may adopt aggressive financial reporting that increases earnings to disguise low prior firm performance and reduce the cost of debt financing. 
Table 7. Aggressive accounting of firms with GCOs within the lowest ROA portfolio

\begin{tabular}{|c|c|c|c|}
\hline \multicolumn{3}{|c|}{$\begin{aligned} R E V_{i t} & +a_{75} L R O A_{i t} * E X P_{i t-1}+a_{76} E X P_{i t}+a_{77} H R O A_{i t} * E X P_{i t}+a_{78} L R O A_{i t} * E X P_{i t} \\
& +a_{75} L R O A_{i t} * E X P_{i t-1}+a_{76} E X P_{i t}+a_{77} H R O A_{i t} * E X P_{i t}+a_{78} L R O A_{i t} * E X P_{i t} \\
& +a_{79} E X P_{i t+1}+a_{80} H_{R O A}{ }_{i t} E X P_{i t+1}+a_{81} L R O A_{i t}{ }^{*} E X P_{i t+1}+e_{i t}\end{aligned}$} & $(10)$ \\
\hline \multirow{2}{*}{ Variable } & \multicolumn{2}{|c|}{ REV } & \\
\hline & Coefficient & (t-stat.) & \\
\hline Intercept & $-0.112 * * *$ & $(-3.15)$ & \\
\hline$H R O A_{i t}$ & $0.125 * *$ & $(2.41)$ & \\
\hline$L R O A_{i t}$ & $0.082 * *$ & $(2.15)$ & \\
\hline$E X P_{i t-1}$ & $0.176^{* * *}$ & $(2.91)$ & \\
\hline$H R O A_{i t} * E X P_{i t-1}$ & -0.126 & $(-1.64)$ & \\
\hline$L R O A_{i t}{ }^{*} E X P_{i t-I}$ & 0.064 & $(0.43)$ & \\
\hline$E X P_{i t}$ & $0.759 * * *$ & $(7.26)$ & \\
\hline$H R O A_{i t} * E X P_{i t}$ & 0.166 & $(1.52)$ & \\
\hline$L R O A_{i t} * E X P_{i t}$ & $-0.523 * * *$ & $(-4.23)$ & \\
\hline$E X P_{i t+1}$ & -0.034 & $(-0.70)$ & \\
\hline$H R O A_{i t}{ }^{*} E X P_{i t+1}$ & $0.073 *$ & $(1.68)$ & \\
\hline$L R O A_{i t}{ }^{*} E X P_{i t+1}$ & $0.164 * * *$ & (2.79) & \\
\hline No. of Obs. & \multicolumn{2}{|c|}{1,083} & \\
\hline F statistics & \multicolumn{2}{|c|}{242.75} & \\
\hline Adj. $\mathrm{R}^{2}$ & \multicolumn{2}{|c|}{0.682} & \\
\hline
\end{tabular}

\subsubsection{Financial Reporting Quality and GCO Firms}

Table 8 presents the test results, using a probit model in the first stage to estimate the probability of issuing a GCO and the relationship between discretionary accruals and firms that received GCOs by a two-step regression. First, Heckman's (1979) first-stage regression analysis is conducted to control for sample selection bias and endogeneity. The first-stage regression shows that high operating losses, bankruptcy risk, a high debt-to-equity ratio, lagged discretionary accruals, low firm performance, and low operating cash flow lead to a high probability of receiving a GCO. Moreover, the inverse mills ratio (Lambda) is estimated from the first-stage regression and includes a twostep regression model as a control variable. In the results of the two-step regression, the coefficient for discretionary accruals for firms that receive GCOs is 0.193 , which is positive and significant at the $1 \%$ level. Positive discretionary accruals are positively associated with firms that receive GCOs, indicating that such firms are characterized by income-increasing earnings management. Additionally, the coefficient for the interaction between GCO firms and negative discretionary accruals is significantly negative, which implies that such firms exhibit income-decreasing earnings management. This result is consistent with findings of prior studies (Bartov, Gul, and Tsui 2000; Bradshaw, Richardson, and Sloan 2001; Amedo, Lizarraga, and Sanchez 2008). 
Table 8. Discretionary accruals of firms with GCOs, using Heckman (1979)'s 2 SLS

\begin{tabular}{|c|c|c|c|c|c|c|c|c|}
\hline \multicolumn{9}{|l|}{ 1st stage: } \\
\hline \multicolumn{9}{|c|}{ 2nd-stage: $\begin{aligned} D A_{i t}\left(P O_{-} \text {or NE_DA }\right)_{i t}= & b_{10}+b_{11} G C O_{i t}+b_{12} L_{a m b d a}+b_{13} S_{I Z E_{i t}}+b_{14} B_{T M}+b_{15} L E V_{i t} \\
& +b_{16} C F O_{i t}+b_{17} G R W_{i t}+b_{18} A B S T A_{i t}+b_{19} Z_{i t}+b_{20} B I G 4_{i t} \\
& +b_{21} L O S S_{i t}+b_{22} R O A_{i t-1}+b_{23} R O A_{i t-1}{ }^{2}+\sum I D+\sum Y R+\varepsilon_{i t}\end{aligned}$} \\
\hline Variable & \multicolumn{2}{|c|}{$\begin{array}{c}\text { 1st stage } \\
\text { Coefficient (p-value) }\end{array}$} & \multicolumn{2}{|c|}{$\begin{array}{c}\text { DA } \\
\text { Coefficient (t-stat.) }\end{array}$} & \multicolumn{2}{|c|}{$\begin{array}{c}\text { PO_DA } \\
\text { Coefficient (t-stat.) }\end{array}$} & \multicolumn{2}{|c|}{$\begin{array}{c}\text { NE_DA } \\
\text { Coefficient (t-stat.) } \\
\end{array}$} \\
\hline Intercept & -0.149 & 0.728 & 0.018 & $(1.01)$ & $-0.064 * *$ & $(-2.37)$ & -0.187 & $(-7.20)$ \\
\hline$A B S \_D A_{i t-1}$ & $1.947 * * *$ & $<.0001$ & & & & & & \\
\hline $\operatorname{LnS} \bar{A} L E_{i t}$ & $-0.117 * * *$ & $<.0001$ & & & & & & \\
\hline$L E V_{i t}$ & $0.071 * * *$ & $<.0001$ & & & & & & \\
\hline$R O A_{i t}$ & $-4.099 * * *$ & $<.0001$ & & & & & & \\
\hline $\mathrm{CASH}_{i t}$ & $-1.233 * * *$ & 0.000 & & & & & & \\
\hline$Z_{i t}$ & $-0.103 * * *$ & $<.0001$ & $0.006^{* * *}$ & (14.77) & $0.003 * * *$ & (5.16) & $-0.002 * * *$ & $(-18.17)$ \\
\hline$C Z_{i t}$ & 0.000 & 0.845 & & & & & & \\
\hline$C F O_{i t}$ & -1.649 & $<.0001$ & $-0.857 * * *$ & $(-72.32)$ & $-0.445 * * *$ & (16.58) & $-0.732 * * *$ & $(-32.95)$ \\
\hline$L T D T_{i t}$ & $2.514 * * *$ & $<.0001$ & & & & & & \\
\hline$C L T D T_{i t}$ & $-2.032 * * *$ & $<.0001$ & & & & & & \\
\hline$B I G 4_{i t}$ & $-0.106^{*}$ & 0.052 & 0.001 & $(0.60)$ & -0.004 & $(-1.45)$ & -0.002 & $(-0.66)$ \\
\hline$L_{O S S} S_{i t}$ & $0.640 * * *$ & $<.0001$ & $-0.079 * * *$ & $(-26.38)$ & $-0.045 * * *$ & $(-8.99)$ & $-0.076^{* * *}$ & $(-18.16)$ \\
\hline$G C O_{i t}$ & & & $0.193 * * *$ & (16.80) & $0.191 * * *$ & (11.85) & $-0.414 * * *$ & $(-23.10)$ \\
\hline$L a m b d a$ & & & $-0.038 * * *$ & $(-6.11)$ & $-0.065 * * *$ & $(-7.26)$ & $0.144 * * *$ & (14.63) \\
\hline$S I Z E_{i t}$ & & & $0.003 * * *$ & $(3.00)$ & $0.005 * * *$ & $(3.47)$ & $0.009 * * *$ & $(6.91)$ \\
\hline$B T M_{i t}$ & & & 0.000 & $(0.96)$ & 0.000 & $(0.58)$ & $-0.000 * * *$ & $(-3.22)$ \\
\hline$L E V_{i t}$ & & & $0.002 * * *$ & $(3.07)$ & $0.004 * * *$ & $(3.86)$ & $0.006 * * *$ & $(7.24)$ \\
\hline$G R W_{i t}$ & & & $0.003 * *$ & $(2.22)$ & 0.000 & $(0.70)$ & -0.006 & $(-1.49)$ \\
\hline$A B S \_T A_{i t}$ & & & $-0.619 * * *$ & $(-61.05)$ & $0.516^{* * *}$ & $(17.40)$ & & \\
\hline$R O \bar{A}_{i t-1}$ & & & $0.066^{* * *}$ & $(5.06)$ & 0.000 & $(0.02)$ & $0.085 * * *$ & (3.99) \\
\hline$R O A^{2}{ }_{i t-1}$ & & & 0.052 & $(1.41)$ & 0.003 & $(0.07)$ & $-0.309 * * *$ & $(-4.29)$ \\
\hline No. of Obs. & 14, & & 14 , & & 7,4 & & 6,7 & \\
\hline F statistics & & & 771 & & 162 & & 193 & \\
\hline Max-rescaled/Adj. $\mathrm{R}^{2}$ & 0.6 & & 0.5 & & 0.3 & & 0.3 & \\
\hline
\end{tabular}

1) $* * *, * *$ and $*$ denote statistical significance at the 1,5 and 10 percent levels in a two-tailed test, respectively.

2) See the Appendix for definitions of the variables.

\section{CONCLUSION}

This study examines whether firms that receive GCOs use accelerated or delayed recognition of current expenses as a method of earnings management depending on firm characteristic variables. We expect that these firms will make different accounting choices according to their financial distress levels and will exhibit low neutrality of matching owing to various incentives in making accounting choices. Low neutrality in accounting will cause early or delayed recognition of current expenses on current revenues.

This study found that firms with GCOs either delay or accelerate recognition of current expenses for current revenues according to their financial conditions. We also found that firms in more severe financial distress, such as higher leverage, loss, and impaired capital, exhibit conservative accounting, which accelerates the recognition of current expenses for current revenues. Conversely, GCO firms in relatively less financial trouble exhibit aggressive accounting, which delays recognition of current expenses. Consistent with the fact that upward (downward) earnings management usually involves positive (negative) discretionary accruals, by estimating the regression of positive $(+)$ and negative (-) discretionary accruals on current revenues, we also found that only GCO firms with negative (-) discretionary accruals adopt conservative accounting.

This study provides empirical evidence that firms under financial distress that receive GCOs manage earnings by either accelerating or delaying recognition of current expenses and demonstrates a significant relationship between revenue-expense matching and discretionary accruals. Our findings contribute to the accounting literature by 
providing empirical evidence that for these firms, earnings management can be better explained by the matching extent or behavior related to discretionary accruals as a proxy for the earnings management approach of firms with GCOs. One key implication of this study is that investors and other stakeholders can use the information obtained on the relationship between revenue-expense matching and financial reporting characteristics of GCO firms to assist them in investment decisions and policies. Because this study uses only Korean data, the results may be limited in terms of generalization and comparability. However, this paper broadly demonstrates that firms with GCOs exhibit different financial reporting behaviors depending on their financial characteristic variables. Future research is needed to verify the financial reporting characteristics of firms that do not receive subsequent GCOs in the following year.

\section{ACKNOWLEDGEMENTS}

This manuscript has not been published previously and is not under consideration by another publisher or journal.

\section{AUTHOR BIOGRAPHIES}

Hakwoon Kim (First Author) is a visiting professor at Business School, SungKyunKwan University, South Korea. $\mathrm{He}$ received his Ph.D. from SungKyunKwan University. His research areas include going-concern audit report, financial reporting, earnings management, earnings quality, conservatism, and value relevance. Email: hankkim@skku.edu.

Sooro Lee (Corresponding Author) is a professor at Business School, Hyupsung University, South Korea. He received his Ph.D. from SungKyunKwan University. His research areas include financial reporting, earnings management, earnings quality, conservatism, and value relevance. Email: srlee1008@uhs.ac.kr

\section{REFERENCES}

Altman, E. I. 1968. "Financial Ratios, Discriminant Analysis and the Prediction of Corporate Bankruptcy” Journal of Finance 23 (4): 589-609.

Amedo, L., F. Lizarraga, and S. Sanchez. 2008. "Going-Concern Uncertainties in Pre-Bankrupt Audit Reports: New Evidence Regarding Discretionary Accruals and Wording Ambiguity" International Journal of Auditing 12 (10): 25-44.

Bartov, E., F. A. Gul, and J. S. L. Tsui. 2000. "Discretionary-Accruals Models and Audit Qualifications." Journal of Accounting and Economics 30 (3): 421-451.

Basu, S. 1997. "The Conservatism Principle and the Asymmetric Timeliness of Earnings" Journal of Accounting and Economics 24 (1): 3-37.

Becker, C. L., M. L. DeFond, J. Jiambalvo, and K. R. Subramanyam. 1998. "The Effect of Audit Quality on Earnings Management." Contemporary Accounting Research 15 (1): 1-24.

Bhattacharya, U., H. Daouk, and M. Welker. 2003. "The World Price of Earnings Opacity.” The Accounting Review 78 (3): 641 678.

Bradshaw, M. T., S. A. Richardson, and R. G. Sloan. 2001. "Do Analysts and Auditors Use Information in Accruals?" Journal of Accounting Research 39 (1): 45-74.

Butler, M., A. J. Leone, and M. Willenborg. 2004. "An Empirical Analysis of Auditor Reporting and Its Association with Abnormal Accruals." Journal of Accounting and Economics 37 (2): 139-165.

Carson, E., N. L. Fargher, M. A. Geiger, C. S. Lennox, K. Raghunandan, and M. Willekens. 2013. “Audit Reporting for GoingConcern Uncertainty: A Research Synthesis." Auditing: a Journal of Practice and Theory 32 (Suppl. 1): 353-384.

Collins, D. W., E. L. Maydew, and I. S. Weiss. 1997. "Change in the Value-Relevance of Earnings and Book Values over the Past Forty Year.” Journal of Accounting and Economics 24 (1): 39-67.

DeAngelo, H., L. DeAngelo, and D. J. Skinner. 1994. "Accounting Choice in Troubled Companies.” Journal of Accounting and Economics 17 (1-2): 113-143.

DeAngelo, L. E. 1981. “Auditor Independence, 'Low Balling', and Disclosure Regulation” Journal of Accounting and Economics 3 (2): 113-127.

Dechow, P. M. 1994. "Accounting Earnings and Cash Flows as Measures of Firm Performance: The Role of Accounting Accruals." Journal of Accounting and Economics 18 (1): 3-42.

DeFond, M. L., and J. Jiambalvo. 1994. "Debt Covenant Violation and Manipulation of Accruals." Journal of Accounting and Economics 17 (1-2): 145-176.

DeFond, M. L., and K. R. Subramanyam. 1998. “Auditor Changes and Discretionary Accruals.” Journal of Accounting and Economics 25 (1): 35-68. 
DeFond, M. L., K. Ragunandan, and K. R. Subramanyam. 2002. "Do Non-audit Service Fees Impair Auditor Independence? Evidence from Going-Concern Audit Opinion" Journal of Accounting Research 40: 1247-1274.

Dichev, I. D., and V. W. Tang. 2008. "Matching and the Changing Properties of Accounting Earnings over the Last 40 Years." The Accounting Review 83 (6): 1425-1460.

Donelson, D. C., R. Jennings, and J. McInnis. 2011. "Changes over Time in the Revenue-Expense Relation: Accounting or Economics?" The Accounting Review 86 (3) : 945-974.

Fargher, N. L., and L. Jiang. 2008. "Changes in the Audit Environment and Auditors' Propensity to Issue Going-Concern Opinions" Auditing: A Journal of Practice \& Theory 27 (2): 55-77.

Francis, J., and K. Schipper. 1999. “Have Financial Statements Lost Their Relevance?” Journal of Accounting Research 37 (2): 319-352.

Geiger, M. A., and D. V. Rama. 2006. “Audit Firm Size and Going-Concern Reporting Accuracy.” Accounting Horizons 20 (1): $1-17$.

Gramling, A. A., J. Krishnan, and Y. Zhang. 2011. “Are PCAOB-Identified Audit Deficiencies Associated with a Change in Reporting Decisions of Triennially Inspected Audit Firms?” Auditing: a Journal of Practice and Theory 30 (3): 59-79.

Heckman, J. J. 1979. "Sample Selection Bias as a Specification Error" Econometrica 47 (1): 153-161.

Holthausen, R. W., D. F. Larcker, and R. G. Sloan. 1995. “Annual Bonus Schemes and the Manipulation of Earnings.” Journal of Accounting and Economics 19 (1): 29-74.

Hyun, J. H., T. S. Ahn, S. Oh, and H. Cho. 2014. "The Changes in Matching between Revenue and Expense: The Effect of Financial Structures.” [in Korean] Korean Accounting Review 39 (1): 43-76.

Jones, J. J. 1991. “Earnings Management During Import Relief Investigations.” Journal of Accounting Research 29 (2): $193-228$.

Kaplan, S. E., and D. D. Williams. 2013. "Do Going Concern Audit Reports Protect Auditors from Litigation? A Simultaneous Equations Approach" The Accounting Review 88 (1): 199-232.

Kim, H. W. 2013. "Financial Reporting Characteristics of Going-Concern Opinion Firms" [in Korean] Korean Accounting Journal 22 (6): 143-178.

Kim, H. W., H. Son, and H. I. Lee. 2013. "Unqualified Opinion with Going-Concern and Conservatism." [in Korean] Korean Accounting Journal 22 (1): 77-105.

Kim, H. W., Y. Sin, and H. I. Lee. 2014. "Earnings Management by Turnaround Strategy Reported in the Going-Concern Audit Report" Korean Accounting Review 39 (5): 91-136.

Kothari, S. P., A. J. Leone, and C. E. Wasley. 2005. "Performance Matched Discretionary Accrual Measures." Journal of Accounting and Economics 39 (1): 163-197.

Lu, T., H. Sapra. 2009. “Auditor Conservatism and Investment Efficiency.” The Accounting Review 84 (6): 1933-1958.

Mutchler, J. F. 1985. “A Multivariate Analysis of the Auditor's Going-Concern Opinion Decision.” Journal of Accounting Research 23 (2): 668-682.

Mutchler, J. F., W. Hopwood, and J. M. McKeown. 1997. "The Influence of Contrary Information and Mitigating Factors on Audit Opinion Decisions on Bankrupt Companies.” Journal of Accounting Research 35 (2): 295-310.

Nah, C. K., and J. H. Choi. 2000. "Earnings Management of Insolvent Firms and Market Reactions." [in Korean] Korean Accounting Review 25 (4): 55-86.

Paek, W. S. 2011a. "The Changes in Accounting Environment and the Matching Principle" [in Korean] Korean Management Review 40 (1): 29-49.

Paek, W. S. 2011b. “The Matching Principle and Earnings Quality” [in Korean] Korean Accounting Review 36 (2): $101-126$.

Paek, W. S. 2012. "Accelerated or Delayed Recognition of Expenses: Earnings Volatility and Persistence." [in Korean] Korean Accounting Review 37 (2): 99-127.

Paek, W. S. 2013. "Firm Life-Cycle Stages, Revenue-Expense Matching, and the Differential Patterns of Expense Recognition" [in Korean] Korean Accounting Review 38 (2): 215-245.

Xu, Y., A. L. Jiang, N. Fargher, and E. Carson. 2011. "Audit Reports in Australia during the Global Financial Crisis.” Australian Accounting Review 21 (1): 22-31. 


\section{APPENDIX}

\begin{tabular}{|c|c|}
\hline GCOit & $\begin{array}{l}\text { dummy variable (equal to } 1 \text { for the firms that received going-concern modified opinions for the current fiscal } \\
\text { year's financial statements and } 0 \text { otherwise); }\end{array}$ \\
\hline ABSDAit-1 & lagged absolute discretionary accruals at firm $\mathrm{i}$ and year $\mathrm{t}-1$; \\
\hline LnSALEit & natural logarithm of total sales; \\
\hline LEVit & total liabilities divided by total book value; \\
\hline ROAit & earnings before tax and interests divided by lagged total assets; \\
\hline CASHit & cash and cash equivalent; \\
\hline Zitit & Altman (1968) Z-score; \\
\hline CZit & change of Altman (1968) Z-score; \\
\hline CFOit & operating cash flow deflated by lagged total assets; \\
\hline LTDTit & long-term debt divided by lagged total assets; \\
\hline CLTDTit & change of long-term debt divided by lagged total assets; \\
\hline BIG4it & $\begin{array}{l}\text { dummy variable (equal to } 1 \text { if firms are audited by one of Big } 4 \text { auditors (Samil, SamJung, AhnJin, HanYoung) } \\
\text { and } 0 \text { otherwise; }\end{array}$ \\
\hline LOSSit & dummy variable ( 1 if net earnings are less than 0 and 0 otherwise); \\
\hline TAit & total accruals (net earnings minus operating cash flow) deflated by lagged total assets; \\
\hline$\triangle$ SALEit & change of sales deflated by lagged total assets; \\
\hline$\triangle A R i t$ & change of accounts receivable deflated by lagged total assets; \\
\hline PPEit & Property, plant and equipment deflated by lagged total assets; \\
\hline DAit & discretionary accruals (Kothari, Leone, and Wasley 2005); \\
\hline PO_DAit & positive discretionary accruals (Kothari, Leone, and Wasley 2005); \\
\hline$N E \_$DAit & negative discretionary accruals (Kothari, Leone, and Wasley 2005); \\
\hline Lambda & inverse Mills ratio of Heckman (1979) estimated going-concern probability by probit model; \\
\hline SIZEit & natural logarithm of total assets; \\
\hline BTMit & total book value divided by market value; \\
\hline GRWit & change of sales deflated by lagged total sales; \\
\hline$A B S \_T A i t$ & absolute total accruals; \\
\hline Zit & Altman's (1968) Z-score; \\
\hline ROAit-1 & lagged earnings before taxes and interest divided by lagged total assets; \\
\hline ROAit-12 & ROA it-1's square; \\
\hline$\sum I D$ & industrial dummy; \\
\hline$\sum Y R$ & year dummy; \\
\hline REVit & total sales and non-operating income divided by lagged total assets at year t-1; \\
\hline EXPit-1 & $\begin{array}{l}\text { total expenses (cost of goods, sales \& administration expenses, and non-operating expenses) divided by lagged } \\
\text { total assets at year t-1; }\end{array}$ \\
\hline EXPit & $\begin{array}{l}\text { total expenses (cost of goods, sales \& administration expenses, non-operating expenses) divided by lagged total } \\
\text { assets at year t; }\end{array}$ \\
\hline EXPit +1 & $\begin{array}{l}\text { total expenses (cost of goods, sales \& administration expenses, non-operating expenses) divided by lagged total } \\
\text { assets at year } t+1 \text {; }\end{array}$ \\
\hline NEGEQit & dummy variable ( 1 if firms have negative equity, otherwise 0 ); \\
\hline HLEVit & $\begin{array}{l}\text { dummy variable ( } 1 \text { if one for the third tertile of portfolio (highest) partitioned by total liability to equity ratio, } \\
\text { otherwise } 0 \text { ); }\end{array}$ \\
\hline LLEVit & $\begin{array}{l}\text { dummy variable ( } 1 \text { if three for the third tertile of portfolio (lowest) partitioned by total liability to equity ratio, } \\
\text { otherwise } 0 \text { ); }\end{array}$ \\
\hline
\end{tabular}




\begin{tabular}{l|l}
\hline HROAit & $\begin{array}{l}\text { dummy variable (1 if one for the third tertile of portfolio (highest) partitioned by earnings before taxes and } \\
\text { interest deflated by lagged total assets, otherwise } 0) ;\end{array}$ \\
\hline LROAit & $\begin{array}{l}\text { dummy variable (1 if three for the third tertile of portfolio(lowest) partitioned by earnings before taxes and } \\
\text { interest deflated by lagged total assets, otherwise } 0) .\end{array}$ \\
\hline HDAit & $\begin{array}{l}\text { dummy variable (1 if one for the third tertile of portfolio (highest) partitioned by discretionary accruals, } \\
\text { otherwise } 0) ;\end{array}$ \\
\hline LDAit & $\begin{array}{l}\text { dummy variable (1 if three for the third tertile of portfolio (lowest) partitioned by discretionary accruals, } \\
\text { otherwise } 0) .\end{array}$ \\
\hline
\end{tabular}




\section{NOTES}

